\title{
Cellulose with Bidentate Chelating Functionality: An Adsorbent for Metal lons from Wastewater
}

\author{
Abdalhadi Deghles, ${ }^{\mathrm{a}, *}$ Othman Hamed, ${ }^{\mathrm{b}, *}$ Mai Azar, ${ }^{\mathrm{b}}$ Bahia Abu Lail, ${ }^{\mathrm{b}}$ Khalil Azzaoui, ${ }^{\mathrm{c}}$ \\ Ahmad Abu Obied, ${ }^{\mathrm{b}}$ and Shehdeh Jodeh ${ }^{\mathrm{b}}$
}

A cellulose derivative with multiple coordination sites for metals composed of cellulose powder and 1,2-pheneylnediamine was synthesized and evaluated as an adsorbent for metal ions from wastewater. The cellulose powder was generated from the solid waste of the olive industry. The adsorption efficiency of the cellulose amine polymer toward Fe(III) and $\mathrm{Pb}$ (II) was investigated as a function of adsorbent dose, temperature, $\mathrm{pH}$, and time. The adsorption parameters that lead to excellent adsorption efficiency were determined. In addition, the polymer showed an excellent extraction efficiency toward approximately 20 metal ions present in a sewage sample. The cellulose amine derivative had several coordination sites that included amine, hydroxyl, and aromatic groups. The diversity and frequency of the coordination sites explained the high efficiency of the polymer for metal ions. The thermodynamic analysis results supported the spontaneous adsorption efficiency of the polymer at room temperature. The adsorption process fit well with the Langmuir adsorption isotherm model.

Keywords: Cellulose powder; Metal ion; 1,2-Phenylene diamine; Wastewater; Cellulose aldehyde; Atomic adsorption spectroscopy

Contact information: a: Graduate Studies Department, Al-Istiqlal University, Ariha, Palestinian Territories; b: Department of Chemistry, College of Science, An-Najah National University, Nablus, Palestinian Territories; c: Laboratory of Mineral Solid and Analytical Chemistry LMSAC, Department of Chemistry, Faculty of Sciences, Mohamed $1^{\text {st }}$ University, P.O. Box 717;

*Corresponding authors: ohamed@najah.edu; daghlas2014@pass.ps

\section{INTRODUCTION}

There is a constantly increasing demand for more sources of fresh water to cover the growing need for food production and human activities (Milieu 2010). Recycling the wastewater released from both industrial and human activities could be an answer for this demand. Wastewater contains a wide variety of toxic materials, both organic and inorganic, depending on the discharging source (Gupta et al. 2015; Hokkanen et al. 2016). These materials are harmful to plants and animals (Gupta and Babu 2009). The inorganic pollutants include toxic metal ions that are discharged mainly from medical activities, agriculture, plumbing, household chemicals, body care products, and other industrial activities. Some of the toxic metal ions that raise a serious concern are $\mathrm{Cd}^{2+}, \mathrm{Cu}^{2+}, \mathrm{Mn}^{2+}$, $\mathrm{Mg}^{2+}, \mathrm{Sr}^{2+}, \mathrm{Al}^{3+}, \mathrm{Co}^{2+}, \mathrm{Ni}^{2+}, \mathrm{Cr}^{3+}, \mathrm{Zn}^{2+}$, and $\mathrm{Pb}^{2+}$ ions (Sud et al. 2008).

Purifying the wastewater from toxic heavy metals is performed by several reported methods, and among these, adsorption is the most applicable (Qaiser et al. 2009) and it receives the most attention because it is highly effective and low-cost (Saravanan and Ravikumar 2015). Among the most effective metal adsorbents is activated carbon. However, it is not optimal in some cases due to the high processing costs (O'Connell et al. 
2008). Additionally, natural-based materials, such as clay, zeolites, and peat, are among the most evaluated materials as adsorbents for toxic heavy metal ions from wastewater (Adeyemo et al. 2017; Chwastowski et al. 2017; Uddin 2017; Bo et al. 2018; Lin et al. 2018). They are the most attractive because they are renewable and available at a relatively low cost (Jodeh et al. 2018; Moa et al. 2018). In addition, other natural products, such as cellulosic materials, lignin, chitosan, and hemicelluloses, received a lot of attention. Several cellulosic-based adsorbents, such as kenaf, cotton linters, wheat straw, wood sawdust, and rice husk, were prepared and investigated as an adsorbent for toxic heavy metal ions such as those mentioned above (Nada et al. 2002; Acar and Eren 2006; Karnitz, Jr. et al. 2007; Doan et al. 2008; Gupta and Babu 2009; Nagy et al. 2013; Vieira et al. 2014; Muhammad et al. 2018). Cellulose nanoparticles (CNC) area promising adsorbent for heavy metal ions (Zelic et al. 2018). Despite all of the rapid progress in the study of natural-based metal adsorbents, many natural-based materials and their derivatives have not been explored as an adsorbent for metal ions.

This work focused on a cellulose powder derivatized with a bidentate chelating agent as a potential new adsorbent for metal ions. The cellulose powder was extracted from solid waste from the olive industry and was reacted with a bifunctional aromatic amine in a three-step process that involved the oxidation of cellulose to aldehyde, the conversion of oxidized cellulose to imine, and the reduction of the imine to an amine. The bifunctional aromatic amine chosen for this purpose is 1,2-pheneylenediamine. The positions of the amino groups (ortho) in addition to the presence of other functional groups (hydroxyl, ether, and aromatic in the target cellulose derivative) makes it a novel adsorbent for metal ions. The prepared cellulose amine polymer (cell-o-PDAm) was evaluated as an adsorbent for $\mathrm{Fe}(\mathrm{III})$ and $\mathrm{Pb}$ (II) from water and other metal ions from a real sample of wastewater.

To the best of our knowledge, the cell-o-PDAm presented in this work is the first example in the literature of cellulose polymer with an aromatic amine bidentate ligand.

\section{EXPERIMENTAL}

\section{Materials}

All reagents used in this study were purchased from Sigma-Aldrich (Jerusalem, Israel) and used as received. The olive industry solid waste (OISW) used in this work was obtained from an olive factory located in city of Tulkarm, Palestine.

\section{Cellulose aldehyde}

A solution of sodium hydroxide ( $8 \%$ by weight) was prepared by dissolving $8.0 \mathrm{~g}$ of sodium hydroxide in $92.0 \mathrm{~mL}$ distilled water. To it was added $6.0 \mathrm{~g}$ of cellulose powder. The produced mixture was stirred for $20 \mathrm{~min}$, diluted with water, filtered, and washed several times with distilled water. Then the mixture was neutralized via dropwise addition of the diluted solution of acetic acid ( $2 \%$ by weight) and washed again with water. A sample of the produced activated cellulose $(5.0 \mathrm{~g}, 0.031 \mathrm{~mol} /$ anhydroglucose repeat unit (AGU)) was added to a beaker, followed by suspended it in $150.0 \mathrm{~mL}$ of distilled water. The flask containing the cellulose suspension was completely wrapped with aluminum foil to isolate it from light. Sodium periodate $(12.8 \mathrm{~g}$, molecular mass $(\mathrm{MM})=213.9 \mathrm{~g} / \mathrm{mol}$, $0.06 \mathrm{~mol}$ ) was added to the cellulose suspension in two portions, $6.4 \mathrm{~g}$ each at $6 \mathrm{~h}$ intervals. The reaction mixture was stirred at $40{ }^{\circ} \mathrm{C}$ for approximately $12 \mathrm{~h}$. The produced cellulose aldehyde was collected via filtration and washed with water $(3 \times 250 \mathrm{~mL})$. Aldehyde 
content (1.89/AGU) was determined according to a previously reported procedure (Kim et al. 2000).

\section{Cellulose o-pheneylendiamine polymer}

Cellulose aldehyde $(2.0 \mathrm{~g}, 0.012 \mathrm{mmol}$ of AGU) and ethanol $(40 \mathrm{~mL})$ were added to a round bottom flask $(100-\mathrm{mL})$ fitted with a magnet stir bar and a reflux condenser. Next, 1,2-diaminobenzene (1.3 g, $12.4 \mathrm{mmol})$ was added to the suspension. The reaction was refluxed for approximately $3 \mathrm{~h}$. The reaction mixture was cooled to room temperature, and sodium borohydride $(0.3 \mathrm{~g})$ was added to the suspension. The reaction mixture was stirred at room temperature for $8 \mathrm{~h}$. It was then treated with a solution of ammonium chloride $(0.5 \%)$ to destroy excess sodium borohydride. The produced cellulose amine polymer was collected through suction filtration and first washed with water, then ethanol, and then air dried.

\section{Methods}

\section{Characterization}

The Fourier transform infrared (FTIR) spectra were recorded on a Nicolet 6700 FTIR spectrometer (Thermo Fisher Scientific, Waltham, MA, USA) equipped with the Smart Split Pea ${ }^{\mathrm{TM}}$ Hemi Micro ATR accessory (International Crystal Laboratories, Garfield, NJ, USA). The following parameters were used: resolution was $4 \mathrm{~cm}^{-1}$, spectral range was $600 \mathrm{~cm}^{-1}$ to $4000 \mathrm{~cm}^{-1}$, and number of scans was 128 . The surface morphology of the cellulose polymer and derivatives were examined using scanning electron microscopy (SEM) (S-4800; Hitachi, Tokyo, Japan) at an acceleration voltage of $3.0 \mathrm{kV}$ after sputter coating the sample with gold (Cressington Sputter Coater; Ted Pella, Inc., Redding, CA, USA). The metal ion analysis was performed using inductively coupled plasma mass spectrometry (ICP-MS) via an iCAP $^{\mathrm{TM}}$ RQ ICP-MS (Thermo Fisher Scientific, Waltham, MA, USA).

\section{Adsorption study}

This work followed a batch adsorption experiment. All experiments were performed in a glass container $(50-\mathrm{mL})$ that was placed in a water bath equipped with a shaker. Different variables on the polymer efficiency for metal adsorption (e.g., metal ion concertation, $\mathrm{pH}$ values, adsorbent dosage, adsorption time, and temperature) were examined. The adsorption study was performed on the two metal ions $\mathrm{Pb}$ (II) and $\mathrm{Fe}$ (III). After each adsorption run, a sample from the mixture was collected via filtration through a $0.45-\mu \mathrm{m}$ syringe filter and subjected to a flame atomic adsorption analysis at $193.7 \mathrm{~nm}$ to determine the residual metal ions concentration. All adsorption experiments were performed in triplicate, and the mean of the three runs was reported. The adsorbent efficiency and the amount of metal ions adsorbed by the cell-o-PDAm adsorbent $q_{\mathrm{e}}(\mathrm{mg} / \mathrm{g})$ was determined according to Eqs. 1 and 2, respectively,

$$
\begin{aligned}
& R(\%)=\frac{C_{0}-C_{e}}{C_{0}} \\
& Q_{e}=\frac{C_{0}-C_{e}}{m} V
\end{aligned}
$$

where $C_{0}$ and $C_{\mathrm{e}}$ are the initial and equilibrium concentrations (ppm) of metal ion in solution, respectively, $Q_{\mathrm{e}}$ is the equilibrium adsorption capacity (ppm), $m$ is the mass of cell-o-PDAm (mg), and $V$ is the volume of the solution (L). 


\section{Wastewater purification}

A sample of sewage water was collected from the sewage system (Nablus, Palestine) and used in this study. The sample was subject to analysis using ICP-MS (performed by the Water Center at An-Najah National University, Nablus, Palestine) to determine the metals' content and their concentrations. A $50.0 \mathrm{~mL}$ sample of the sewage water was placed in an Erlenmeyer flask and its $\mathrm{pH}$ values were adjusted to 6.3. Each sample received $0.1 \mathrm{~g}$ of cell-o-PDAm. The mixture was shaken at room temperature for $30 \mathrm{~min}$. A sample was withdrawn from the mixture with a syringe, pushed through a 0.45 $\mu \mathrm{m}$ syringe filter, and subjected to ICP-MS analysis for any residual metal ions concentrations.

\section{RESULTS AND DISCUSSION}

\section{Product Analysis}

The cellulose powder was extracted from olive industry solid waste following a process of pulping and bleaching, as reported in previous studies (Hamed et al. 2012, 2014). The produced cellulose powder was oxidized to cellulose aldehyde by reacting it with sodium periodate, following a published procedure (Kim et al. 2000). The reaction was performed under neutral conditions at $40{ }^{\circ} \mathrm{C}$ for $12 \mathrm{~h}$. The FTIR spectrum of the oxidized celluloses is shown in Fig. 1a. The most noticeable peaks for cellulose dialdehyde (CDA) were observed at $1732 \mathrm{~cm}^{-1}, 1425,1375$, and $1140 \mathrm{~cm}^{-1}$, assigned to $\mathrm{C}=\mathrm{O}$ (aldehyde), $\mathrm{CH}_{2}$ asymmetric bending, $\mathrm{C}-\mathrm{O}$ stretching of ether and alcohol, and $\mathrm{C}-\mathrm{O}-\mathrm{C}$ stretching of $\beta$-glycosidic linkage, respectively. The weak band at $1732 \mathrm{~cm}^{-1}$ was due to the hydration and acetal formation (Lázaro-Martínez et al. 2010; Algarra et al. 2019). The mechanism is depicted in Fig. $1 \mathrm{~b}$.

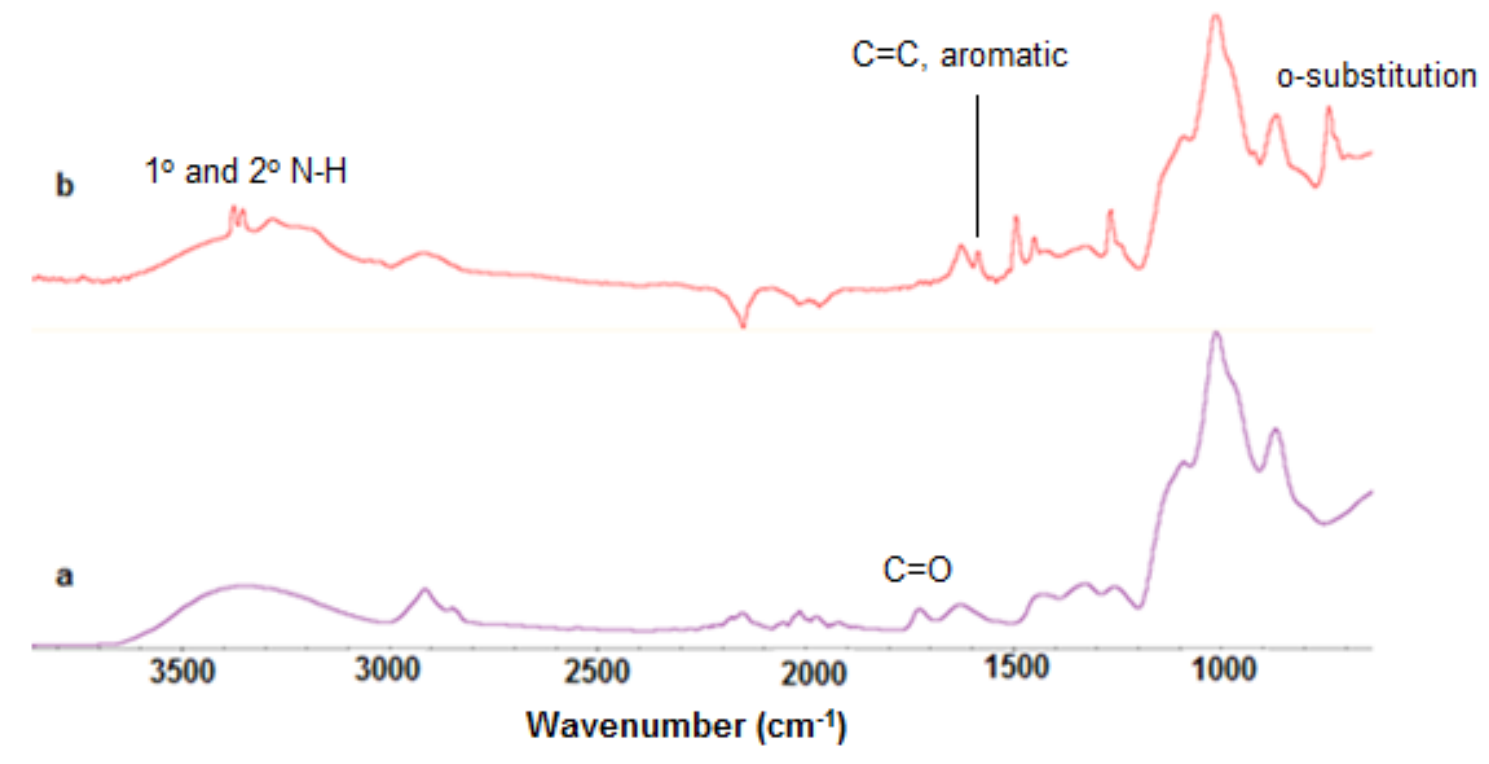

Fig. 1. (a) FTIR spectrum of cellulose aldehyde and (b) FTIR spectrum of cellulose amine 


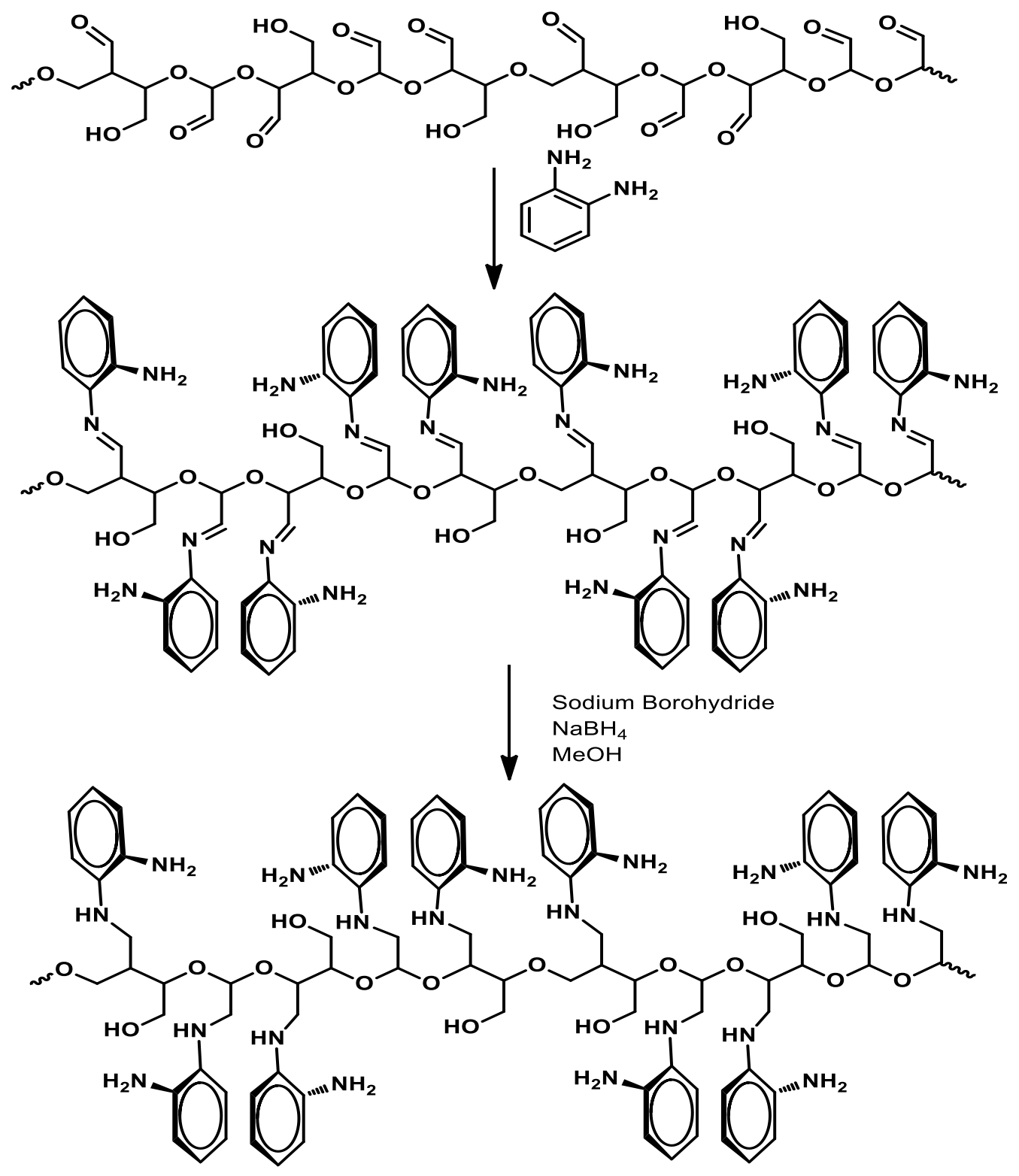

Fig. 2. Schematic showing the molecular structures of products reaction condition

The X-ray diffraction (XRD, D8 Advance; Bruker, Hamburg, Germany) patterns of cellulose aldehyde and cell-o-PDAm are shown in Fig. 1S. The intensity of the crystalline peaks at $2 \theta=16^{\circ}$ and $2 \theta=32^{\circ}$ in cellulose aldehyde broadened with some shift in their values. This could indicate a loss of crystallinity. The loss of crystallinity was attributed to the ring opening of glucopyranose, which causes a disruption and loss of $\mathrm{H}$ bonding, and consequently, a loss of crystallinity (Kim et al. 2000; Heinze and Liebert 2001). The XRD of cell-o-PDAm showed that the cellulose crystallinity completely changed as the new compound emerged.

The aldehyde carbonyl group had an electrophilic carbon, therefore undergoing a condensation reaction with a nucleophile, such as amine, to form an imine after the loss of a water molecule. Reduction of the cellulose imine with sodium borohydride produces cellulose amine, as shown in Fig. 2. The produced amine had several coordination sites for 
metal ions, including amines, hydroxyl, and aromatic functionalities. A representative molecular structure of cell-o-PDAm is shown in Fig. 2.

The FT-IR spectra of cell-o-PDAm (Fig. 1a) showed two peaks at $1635 \mathrm{~cm}^{-1}$ and $1610 \mathrm{~cm}^{-1}$, corresponding to a primary amine and an aromatic $\mathrm{C}=\mathrm{C}$, respectively. The broad adsorption peak at approximately $3350 \mathrm{~cm}^{-1}$ was composed of several peaks originating from $\mathrm{O}-\mathrm{H}$ or $\mathrm{N}-\mathrm{H}$ stretching vibrations of primary and secondary amines. Additionally, the IR spectrum showed a peak at $2930 \mathrm{~cm}^{-1}$ that could have been attributed to the symmetric and asymmetric stretching vibration of the $\mathrm{C}-\mathrm{H}$ bond. The peak at $750 \mathrm{~cm}^{-1}$ could be related to ortho substitution of phenylene diamine.

The SEM images of cellulose aldehyde, and the cell-o-PDAm prepared from it, are shown in Fig. 3.
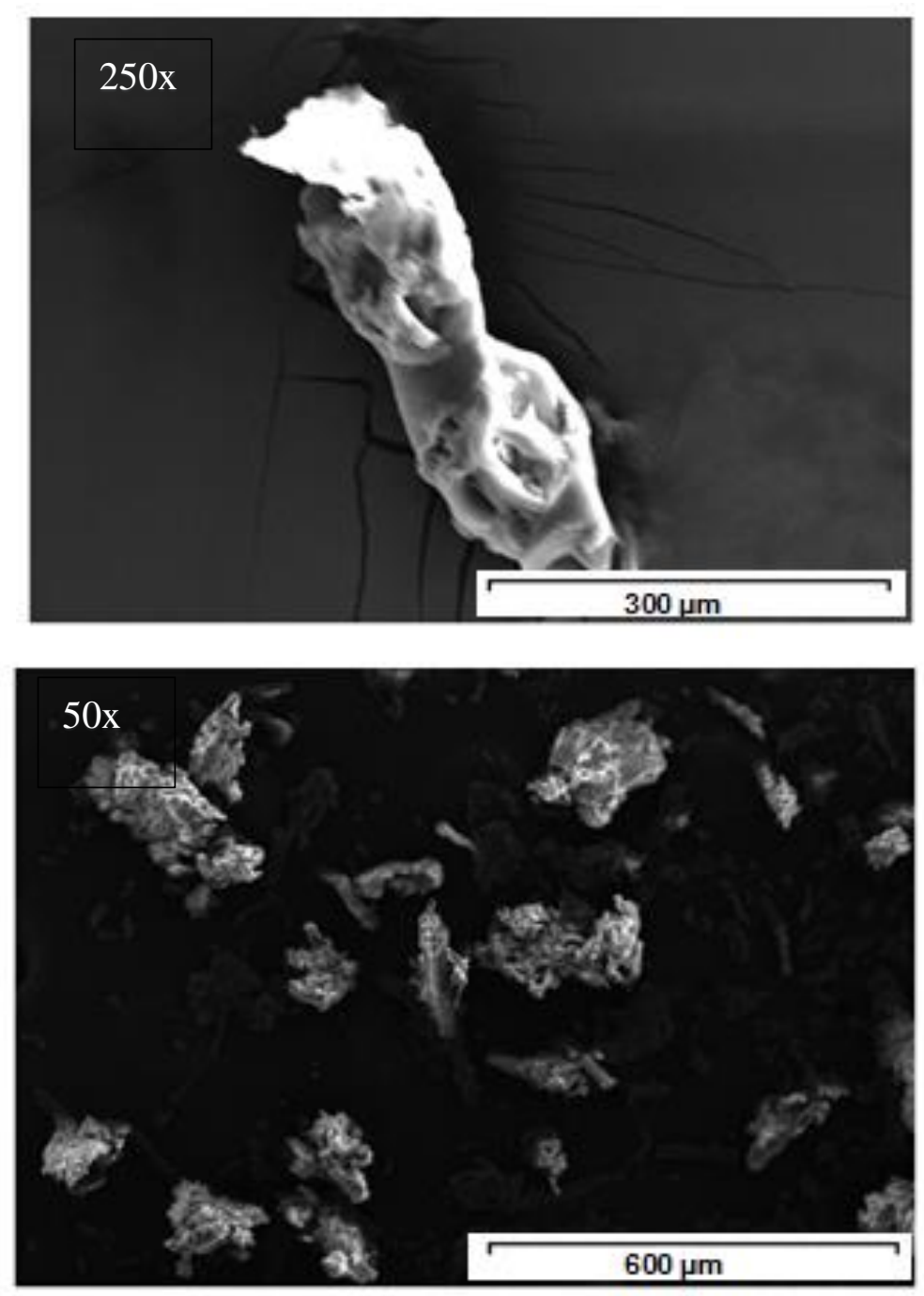

Fig. 3. SEM images of (a) cellulose aldehyde and (b) cell-o-PDAm at magnifications of 250x and 50x, respectively

The cellulose aldehyde image showed that the cell structure had been damaged. The morphology of cell-o-PDAm as shown in its image was a highly porous spongy type. The solubility of cell-o-PDAm in water was evaluated by suspending a known weight (1.00 g) 
of cell-o-PDAm in water $(50 \mathrm{~mL})$ for approximately $12 \mathrm{~h}$ before being filtered and dried. It showed minimal weight loss within the experimental error.

\section{Metal Ions Extraction}

The extraction was completed using a batch adsorption process. During this process, a known weight (ranging from $0.5 \mathrm{mg} / \mathrm{mL}$ to $5.0 \mathrm{mg} / \mathrm{mL}$ metal solution) of cello-PDAm was suspended in an aqueous solution of metal ions, filtered, and analyzed. The analysis was performed on the filtrate to determine the concentration of the extracted ions. The effects of several variables (e.g., adsorbent dosage, extraction time, temperature, and $\mathrm{pH})$ were evaluated to determine the best conditions for the highest adsorption efficiency. The adsorption study was performed on lead $(\mathrm{Pb})$ and iron $(\mathrm{Fe})$ ions.

\section{Optimum Adsorbent Dosage}

The dosage that provided the lowest residual concentration of metal ions was chosen as the optimal dosage. This was achieved by performing the experiment with 50 $\mathrm{mL}$ each of $\mathrm{Fe}(\mathrm{III})$ and $\mathrm{Pb}(\mathrm{II})$, with a concentration of $30 \mathrm{ppm}, \mathrm{pH}$ value of 6.3 , adsorption time of $30 \mathrm{~min}$, and performed at room temperature. The effect of the adsorbent dosage on the removal of $\mathrm{Fe}$ (III) and $\mathrm{Pb}$ (II) ions is shown in Fig. 4a. As shown in the figure, the amount of metal extracted increased when increasing the polymer dosage. Metal ion removal reached approximately $67.8 \%$ and $88.1 \%$ for $\mathrm{Pb}(\mathrm{II})$ and $\mathrm{Fe}(\mathrm{III})$, respectively, at a $2.0 \mathrm{mg} / \mathrm{mL}$ dose of cell-o-PDAm. At dosages higher than $2.0 \mathrm{mg} / \mathrm{mL}$, it became nearly constant. This was because the adsorption process was controlled by two mechanisms, diffusion and surface coordination. An increase in the dosage resulted in the number of available binding sites increasing, and thus the ion removal increased. When all sites on the surface were occupied, the diffusion process began. It is controlled by osmosis; when the concentration of the metal ions adsorbed by the polymer are equal to that of the solution, the adsorption stops (Abdel-Ghani et al. 2007).

\section{Effect of Initial Ion Concentration}

The effect of the initial ion concentration on the adsorption efficiency was evaluated under the following adsorption conditions: adsorption time was $30 \mathrm{~min}$, adsorbent dose was $2.0 \mathrm{mg} / \mathrm{mL}$, and $\mathrm{pH}$ was 6.3 . The amines' functional groups were in Lewis base form at this $\mathrm{pH}$ value. As shown in Fig. $4 \mathrm{~b}$, the highest removal was at the concentration of $10 \mathrm{ppm}$. At this concentration, the percent of ions removed reached $88.3 \%$ and $83.2 \%$ for $\mathrm{Fe}(\mathrm{III})$ and $\mathrm{Pb}(\mathrm{II})$, respectively. At concentrations higher than $10 \mathrm{ppm}$, the removal started to gradually decline. The results indicated that at low concentrations of metal ions, the driving force for adsorption was controlled by the ion diffusion (Sahmoune et al. 2011). At high concentrations, the availability of the binding sites was the limiting factor, and the number of available sites was governed by the adsorbent dosage. According to the obtained results, at a concentration of approximately $10 \mathrm{ppm}$, the binding sites were almost saturated for this reason. However, concentrations higher than $10 \mathrm{ppm}$ resulted in the rate of metal removal decreasing. 

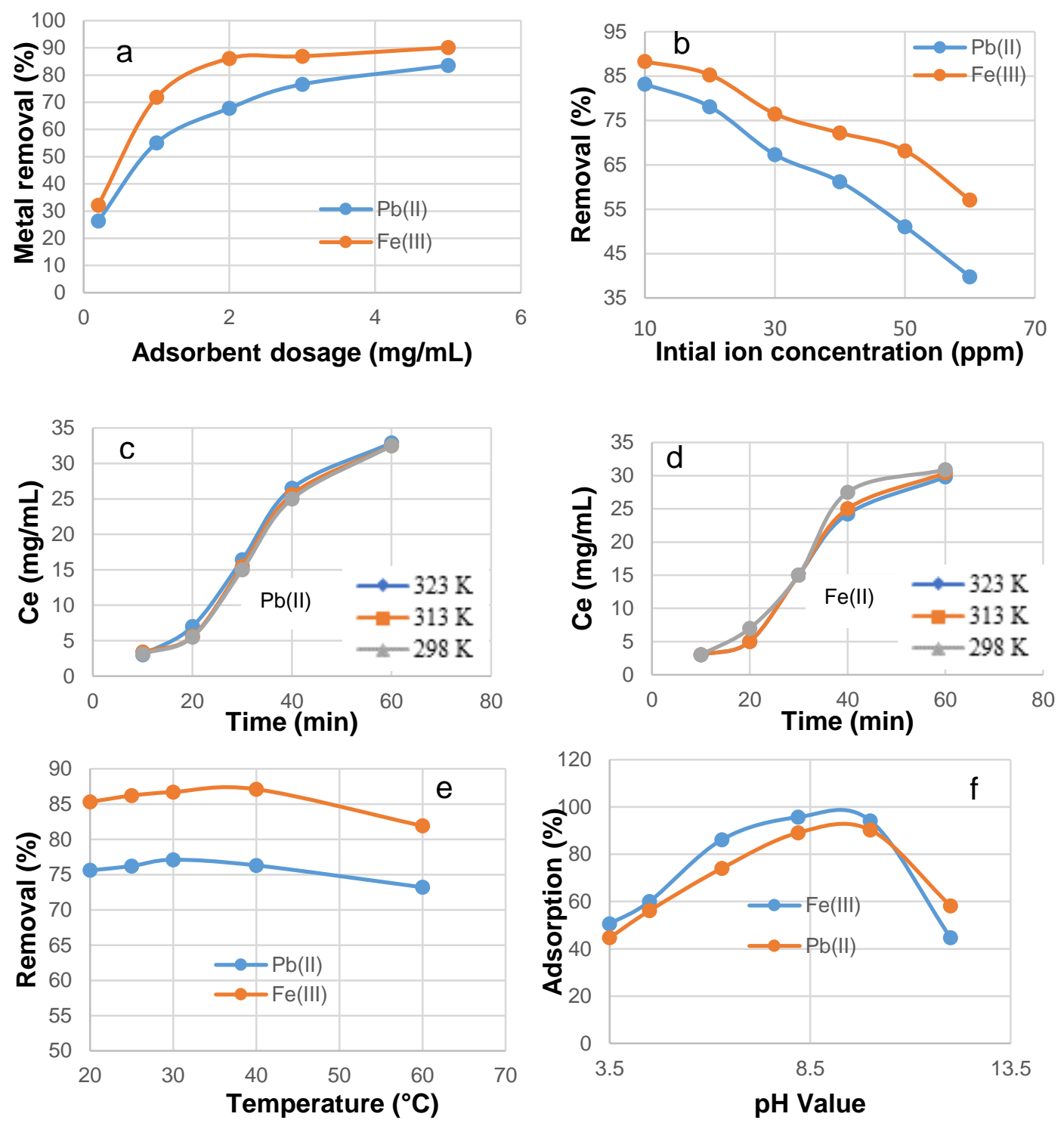

Fig. 4. Effect of (a) adsorbent dose, (b) initial ion concentration, (c) adsorption time for $\mathrm{Pb}(\mathrm{II})$, (d) adsorption time for Fe(III), (e) temperature, and (f) $\mathrm{pH}$ on the metal removal by cell-o-PDAm

\section{Effect of Contact Time}

Adsorption of the metal ions $\mathrm{Pb}(\mathrm{II})$ and $\mathrm{Fe}(\mathrm{III})$ by cell-o-PDAm as a function of

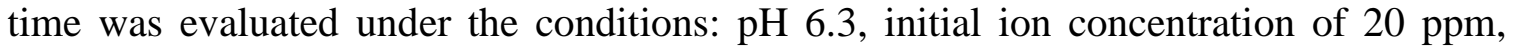
adsorption temperature of $25^{\circ} \mathrm{C}$, and the adsorbent dose was $2.0 \mathrm{mg} / \mathrm{mL}$. As shown in Figs. $4 \mathrm{c}$ and $4 \mathrm{~d}$, the adsorbed metal ions rapidly increased for the first $40 \mathrm{~min}$ due to the availability of the binding sites. Then, the adsorption rate became almost constant for the next $20 \mathrm{~min}$ and reached equilibrium after $40 \mathrm{~min}$. The results indicated that at this period, almost all the coordination sites are occupied (Liu et al. 2013). A contact time of $40 \mathrm{~min}$ was chosen as the optimal contact time. The two ions showed nearly similar adsorption behavior with time. 


\section{Effect of Temperature}

The effect of temperature on the adsorption of metal was evaluated under the conditions: $\mathrm{pH}$ 6.3, initial metal ion concentration of $30 \mathrm{ppm}$, adsorption time of $40 \mathrm{~min}$, and the adsorbent dose was $2.0 \mathrm{mg} / \mathrm{mL}$ (Fig. 4e). The adsorption efficiency showed no dependence on the temperature. Up to approximately $60{ }^{\circ} \mathrm{C}$, the adsorption efficiency was almost constant.

\section{Effect of pH}

The effect of the adsorption efficiency as a function of the $\mathrm{pH}$ value is shown in Fig. 4f. The $\mathrm{pH}$ value was a critical factor in metal adsorption because the $\mathrm{pH}$ value could control the surface charge of the polymer. At low pH values $(\leq 3.0)$, the amine is in the salt form $\left(-\mathrm{NR}_{2} \mathrm{H}_{2}^{+}\right)$. For this reason, the adsorption efficiency was the minimum (approximately 20\%). However, at $\mathrm{pH}$ values higher than 3.0, the lone pair of electrons on amine $\mathrm{N}$ became more available, causing the amine group to behave as a metal binding agent. The highest efficiency was observed at $\mathrm{pH}$ 8.6. At higher $\mathrm{pH}$ values, the adsorption efficiency started to decline. The formation of metal oxides and metal hydroxides at $\mathrm{pH}$ higher than 9.0 could be the reason for the decreasing adsorption efficiency.

\section{Wastewater Purification from Metals}

A sample of wastewater was collected from a sewer system and was treated with cell-o-PDAm. A photograph of the wastewater sample before and after its treatment is shown in Fig. S2. The metal content of the sample before and after purification is summarized in Table 1.

Table 1. Metal Concentration of Wastewater before and after Treatment, $\mathrm{pH} 6.8$

\begin{tabular}{|c|c|c|c|}
\hline Metal lon & Before $(\mathrm{ppm})$ & After $(\mathrm{ppm})$ & Removal (\%) \\
\hline $\mathrm{Ag}$ & 38.1 & 0.635 & 98.3 \\
\hline $\mathrm{Al}$ & 4680 & 52.2 & 98.9 \\
\hline $\mathrm{Pb}$ & 12.5 & 1.6 & 98.7 \\
\hline $\mathrm{Cu}$ & 103 & 0.644 & 62.1 \\
\hline $\mathrm{Cd}$ & 0.67 & 0.07 & 89.6 \\
\hline $\mathrm{Cr}$ & 523 & 43.1 & 91.8 \\
\hline $\mathrm{Co}$ & 12.5 & 1.07 & 91.4 \\
\hline $\mathrm{Fe}$ & 8156 & 383 & 95.3 \\
\hline $\mathrm{Ga}$ & 2.4 & 0.48 & 80 \\
\hline $\mathrm{Rb}$ & 35.4 & 20.7 & 41.5 \\
\hline $\mathrm{Li}$ & 6.7 & 5.3 & 21 \\
\hline $\mathrm{Mn}$ & 167 & 25.3 & 85 \\
\hline $\mathrm{Mo}$ & 9.7 & 2.4 & 75.3 \\
\hline $\mathrm{Ni}$ & 43 & 11 & 74.7 \\
\hline $\mathrm{Sr}$ & 609 & 231 & 62 \\
\hline $\mathrm{Cs}$ & 0.31 & 0.13 & 58.1 \\
\hline $\mathrm{V}$ & 16 & 1.4 & 92 \\
\hline $\mathrm{Zn}$ & 696 & 19.3 & 98 \\
\hline
\end{tabular}


The results showed that the cell-o-PDA polymer had excellent efficiency toward most of the metals present in the wastewater sample, i.e., the removal exceeded $90 \%$ for several of them.

The high efficiency of the cellulose amine polymer toward the metal ions was possibly related to the unique structure that was composed of several coordination sites that include amine, hydroxyl, and aromatic groups.

\section{Adsorption Analysis}

The Langmuir (Eq. 3) and Freundlich isotherm (Eq. 4) methods were used to evaluate the distribution of metal ions on the surface of cell-o-PDAm after reaching the equilibrium at a constant temperature (Limousin et al. 2007; Azzaoui and Mejdoubi 2014). The Langmuir model assumes the formation of a monolayer of adsorbate on a homogeneous surface of an adsorbent (Brdar et al. 2012). However, the Freundlich model describes the adsorption between the adsorbate molecule and the adsorbent with a heterogeneous surface. Below is Eq. 3,

$$
\text { Langmuir isotherm model: } \frac{C_{e}}{Q_{e}}=\frac{1}{q_{\max }} C_{e}+\frac{1}{q_{\max } K_{L}}
$$

where $C_{\mathrm{e}}$ is the equilibrium concentration of metal ion (ppm), $Q_{\mathrm{e}}$ is the amount of adsorbate adsorbed per unit mass of cellulose amine at equilibrium $(\mathrm{mg} / \mathrm{g}), Q_{\max }$ is the theoretical maximum monolayer adsorption capacity of the adsorbent $(\mathrm{mg} / \mathrm{g})$, and $K_{\mathrm{L}}$ is the Langmuir isotherm constant related to the adsorption energy $(\mathrm{L} / \mathrm{mg})$. Equation 4 is as follows,

$$
\text { Freundlich isotherm model: } \ln \left(q_{\mathrm{e}}\right)=\ln k_{\mathrm{f}}+\frac{1}{n} \ln C_{\mathrm{e}}
$$

where $K_{\mathrm{F}}$ and $\frac{1}{n}$ are empirical constants that indicate the relative adsorption capacity and intensity related to the affinity of the metal, respectively.

The Langmuir isotherm model also can distinguish whether the adsorption was favorable or not by using the dimensionless constant separation factor shown in Eq. 5,

$$
R_{\mathrm{L}}=\frac{1}{1+K_{\mathrm{L}} C_{0}}
$$

where $K_{\mathrm{L}}$ is the Langmuir constant and $\mathrm{C}_{0}$ is the initial adsorbate concentration. The adsorption is unfavorable if the $R_{\mathrm{L}}$ value is greater than 1 . However, if the value of $R_{\mathrm{L}}$ is between 1 and 0 , then the adsorption is favorable. The adsorption is linear if $R_{\mathrm{L}}=1$.

All fitting parameters obtained from Fig. 5 are summarized in Table 2. The coefficients of determination for the Langmuir isotherm model (Table 2) were much higher than those for the Freundlich isotherm model, indicating that the adsorption of $\mathrm{Pb}$ (II) and $\mathrm{Fe}$ (III) ions followed the Langmuir isotherm model (Eq. 4) because the $\mathrm{Pb}$ and $\mathrm{Fe}$ ions were equally and homogeneously spread over the cell-o-PDAm porous surfaces. The separation factor $R_{\mathrm{L}}$, which was calculated for various amounts of adsorbents for cell-oPDAm, was $0<R_{\mathrm{L}}<1$ (Table 2).

The $R$ values were much smaller than 1, indicating a high affinity of cell-o-PDAm for $\mathrm{Pb}(\mathrm{II})$ and $\mathrm{Fe}(\mathrm{III})$. 

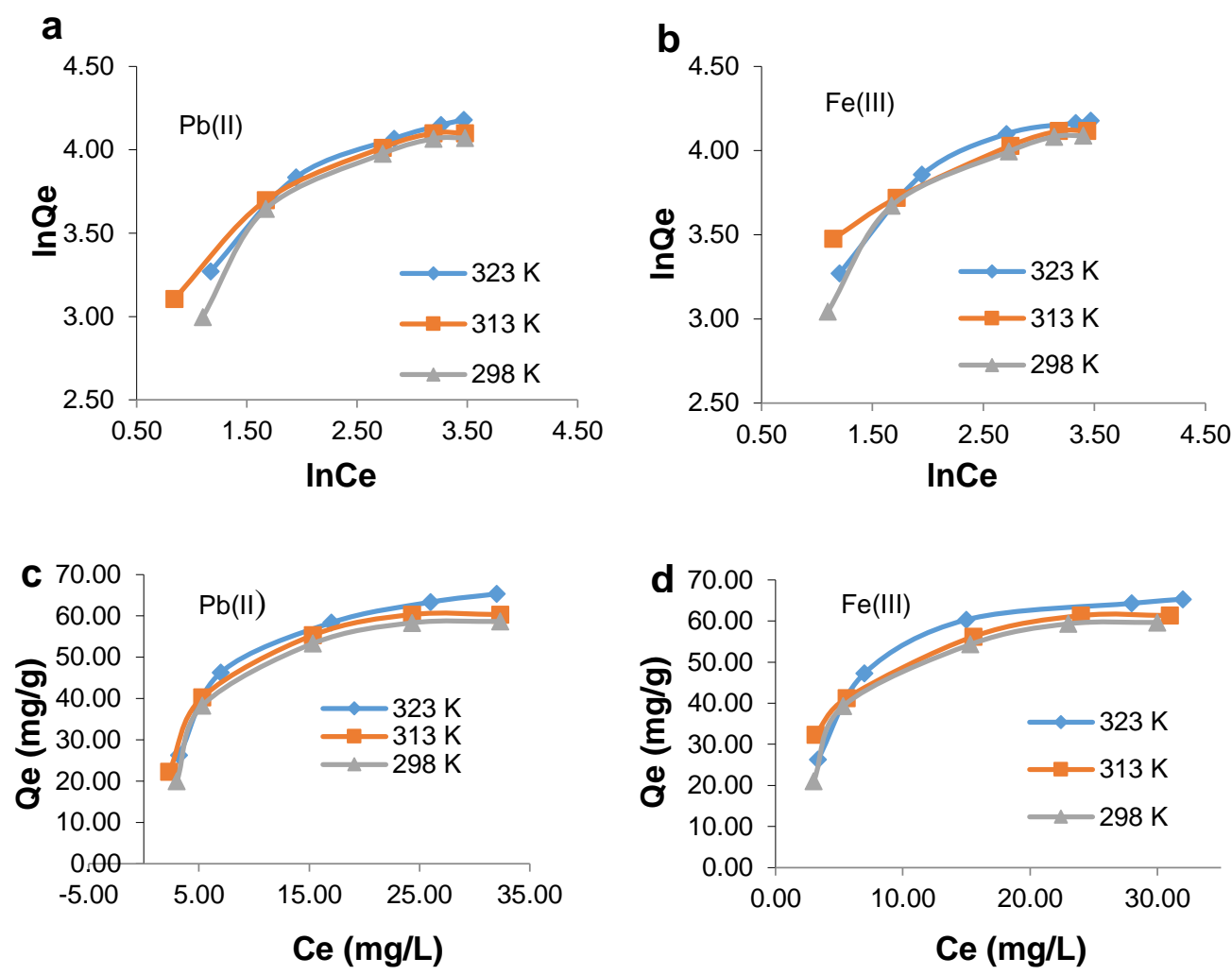

Fig. 5. Langmuir of (a) $\mathrm{Pb}(\mathrm{II})$ and (b) $\mathrm{Fe}(\mathrm{III})$; Freundlich adsorption model of (c) $\mathrm{Pb}(\mathrm{II})$ and (d) $\mathrm{Fe}(\mathrm{III})$ ions on cell-o-PDAm at various temperatures

Table 2. Langmuir and Freundlich Parameters for the Adsorption of $\mathrm{Pb}(\mathrm{II})$ and $\mathrm{Fe}$ (III) lons by cell-o-PDAm

\begin{tabular}{|c|c|c|c|c|c|c|c|}
\hline \multicolumn{2}{|c|}{} & \multicolumn{3}{|c|}{$\mathrm{Fe}(\mathrm{III})$} & \multicolumn{3}{c|}{$\mathrm{Pb}(\mathrm{II})$} \\
\hline \multicolumn{2}{|c|}{ Temperature $(\mathrm{K})$} & 298 & 313 & 323 & 298 & 313 & 323 \\
\hline \multirow{4}{*}{$\begin{array}{c}\text { Langmuir } \\
\text { Isotherm }\end{array}$} & $\mathrm{Q}^{0}(\mathrm{mg} / \mathrm{g})$ & 2.3792 & 2.7137 & 2.6616 & 2.3873 & 2.1645 & 2.3873 \\
\cline { 2 - 8 } & $\left.\mathrm{KL}_{\mathrm{L}} \mathrm{L} / \mathrm{mg}\right)$ & 0.1540 & 0.1259 & 0.1274 & 0.1050 & 0.1112 & 0.105 \\
\cline { 2 - 8 } & $\mathrm{RL}_{\mathrm{L}}$ & 0.01282 & 0.01563 & 0.01545 & 0.01869 & 0.01754 & 0.01869 \\
\cline { 2 - 8 } & $\mathrm{R}^{2}$ & 0.8705 & 0.9176 & 0.9178 & 0.9607 & 0.8771 & 0.967 \\
\hline \multirow{3}{*}{$\begin{array}{c}\text { Freundlich } \\
\text { Isotherm }\end{array}$} & $1 / n$ & 0.9016 & 0.6095 & 0.8466 & 0.9108 & 0.7149 & 0.824 \\
\cline { 2 - 8 } & $K_{\mathrm{F}}(\mathrm{L} / \mathrm{mg})$ & 21.3427 & 29.7967 & 24.229 & 20.4750 & 26.222 & 24.366 \\
\cline { 2 - 8 } & $\mathrm{R}^{2}$ & 0.9507 & 0.995 & 0.9543 & 0.945 & 0.9867 & 0.9762 \\
\hline
\end{tabular}

\section{Kinetics Adsorption}

The two kinetic models, pseudo-first-order (Eq. 7) and pseudo-second-order (Eq. 8 ), were used to describe the kinetics of the adsorption process, comprising the adsorption rates and adsorption mechanism of the metal ions $\mathrm{Pb}$ (II) and $\mathrm{Fe}$ (III) onto the surface of cell-o-PDAm (Zhao et al. 2014; Jodeh et al. 2016):

$$
\begin{aligned}
& \ln \left(q_{\mathrm{e}}-q_{\mathrm{t}}\right)=\ln q_{e}-K_{1} t \\
& \frac{t}{q_{\mathrm{t}}}=\frac{1}{k_{2 q_{e}^{2}}}+\frac{t}{q_{e}}
\end{aligned}
$$


In addition, the intraparticle diffusion model (Eq. 9) was used to determine the ratedetermining step during the metal ion adsorption,

$$
Q_{\mathrm{t}}=K_{\mathrm{id}} t^{\frac{1}{2}}+Z
$$

where $Q_{\mathrm{e}}$ and $Q_{\mathrm{t}}$ are the adsorption capacities at equilibrium $(\mathrm{mg} / \mathrm{g}), t$ is the various times ( $\mathrm{min}), K_{1}$ is the pseudo-first-order rate constant ( $\left.1 / \mathrm{min}\right), K_{2}$ is the pseudo-second-order rate constant $(\mathrm{g} / \mathrm{mg} \mathrm{min}), K_{\text {id }}$ is the intraparticle diffusion rate constant $\left(\mathrm{mg} / \mathrm{gmin}^{1 / 2}\right)$, and $Z$ $(\mathrm{mg} / \mathrm{g})$ was used to conclude the thickness of the boundary layer.

Additionally, the liquid film diffusion model (Eq. 10) was employed to investigate whether the transport of metal ions from the liquid phase to the solid phase boundary plays a role in the adsorption process,

$$
\ln (1-F)=-K_{\mathrm{f}} d t
$$

where $F$ is the fractional attainment of equilibrium $\left(F=q_{\mathrm{t}} / q_{\mathrm{e}}\right), q_{\mathrm{e}}$ is the adsorption capacity of the sorbent at equilibrium $\left(\mathrm{mg} \times \mathrm{g}^{-1}\right)$, and $K_{\mathrm{f}}$ is the liquid film diffusion constant. A linear plot of $\ln (1-\mathrm{F})$ versus $t$ with zero intercept would suggest that the kinetics of the adsorption process was controlled by diffusion from the liquid surrounding the solid sorbent.

The values of all the parameters shown in the above equations are summarized in Table 3 and Fig. 5.

Table 3A. The Pseudo-second-order Model for Adsorption of $\mathrm{Pb}$ (II) and $\mathrm{Fe}$ (III) ions by Cell-o-PDAm

\begin{tabular}{|c|c|c|c|c|c|c|c|c|c|}
\hline$T(\mathrm{~K})$ & \multicolumn{3}{|c|}{298} & \multicolumn{3}{c|}{313} & \multicolumn{3}{c|}{323} \\
\hline & $\begin{array}{c}K_{2} \\
(\mathrm{~g} / \mathrm{mg} \times \\
\mathrm{min})\end{array}$ & $\begin{array}{c}Q_{\text {cal }} \\
(\mathrm{mg} / \mathrm{g})\end{array}$ & $\mathrm{R}^{2}$ & $\begin{array}{c}K_{2} \\
(\mathrm{~g} / \mathrm{mg} \times \\
\mathrm{min})\end{array}$ & $\begin{array}{c}Q_{\text {cal }} \\
(\mathrm{mg} / \mathrm{g})\end{array}$ & $\mathrm{R}^{2}$ & $\begin{array}{c}K_{2}(\mathrm{~g} / \mathrm{mg} \\
\times \mathrm{min})\end{array}$ & $\begin{array}{c}Q_{\text {cal }} \\
(\mathrm{mg} / \mathrm{g})\end{array}$ & $\mathrm{R}^{2}$ \\
\hline $\mathrm{Fe}(\mathrm{III})$ & 0.3568 & 416.5 & 0.9868 & 0.3911 & 533.5 & $\begin{array}{c}0.97 \\
45\end{array}$ & 0.3814 & 622.8 & 0.9845 \\
\hline $\mathrm{Pb}(\mathrm{II})$ & 0.3568 & 152.9 & 0.9866 & 0.3907 & 196.3 & $\begin{array}{c}0.97 \\
48\end{array}$ & 0.3813 & 230.7 & 0.9836 \\
\hline
\end{tabular}

Table 3B. The Intraparticle Diffusion Parameters of $\mathrm{Pb}(\mathrm{II})$ and $\mathrm{Fe}(\mathrm{III})$ lons onto Cell-o-PDAm

\begin{tabular}{|c|c|c|c|c|c|c|c|c|c|}
\hline$T(\mathrm{~K})$ & \multicolumn{3}{|c|}{298} & \multicolumn{3}{c|}{313} & \multicolumn{3}{c|}{323} \\
\hline & $K_{\text {id }}$ & $Z$ & $\mathrm{R}^{2}$ & $K_{\text {id }}$ & $Z$ & $\mathrm{R}^{2}$ & $K_{\text {id }}$ & $Z$ & $\mathrm{R}^{2}$ \\
\hline $\mathrm{Fe}(\mathrm{III})$ & 1.041 & 1.92 & 0.931 & 1.126 & 1.851 & 0.905 & 1.333 & 1.689 & 0.944 \\
\hline $\mathrm{Pb}(\mathrm{II})$ & 0.905 & 1.08 & 0.934 & 1.036 & 0.871 & 0.942 & 1.083 & 0.96 & 0.963 \\
\hline
\end{tabular}

The value of $K_{1}$ was obtained by plotting $\ln \left(q_{\mathrm{e}}-q_{\mathrm{t}}\right) v s . t$ (Fig. S3a), while the $K_{2}$ values and the adsorption capacity $q_{\mathrm{e}}$ were calculated from the slope and the intercept of plotting $t / q_{\mathrm{t}} v s$. $t$ (Fig. S3b). The values for $K_{\mathrm{id}}$ and $\mathrm{Z}$ were obtained from plotting $q_{\mathrm{t}} v s . t^{1 / 2}$ (Fig. S3c). When the experimental data was plotted for both the pseudo-first-order and the second-pseudo-order kinetics, the coefficients of determination $\left(\mathrm{R}^{2}\right)$ for the pseudosecond-order (0.91 to 0.973$)$ were higher than the pseudo-first-order (0.891). The 
calculated $q_{\mathrm{e}}$ values $(2.675 \mathrm{mg} / \mathrm{g}, 15.252 \mathrm{mg} / \mathrm{g}$, and $20.856 \mathrm{mg} / \mathrm{g}$ ) for the pseudo-secondorder (see Table 3 and Fig. S3c) were close to the experimental $q_{\mathrm{e}}$ values $(2.133 \mathrm{mg} / \mathrm{g}$, $13.91 \mathrm{mg} / \mathrm{g}$, and $18.786 \mathrm{mg} / \mathrm{g}$ ), indicating that the adsorption process of metal ions on the surfaces of cell-o-PDAm followed the pseudo-second-order.

All plots shown in Fig. S3 did not pass through the origin, indicating the presence of more than one rate-determining step in the absorption processes. From the initial linearity of the graphs shown in Fig. S3c, the adsorption process of $\mathrm{Pb}$ (II) and $\mathrm{Fe}$ (III) ions occurred first via an instant adsorption stage (on the exterior surface of cell-o-PDAm), which may have resulted in a chemical complexation between the metal ions, amines, and other functionalities (Guo et al. 2008). Additionally, the rest of the stages were linear, indicating the gradual adsorption and the intraparticle diffusion rate limiting step of $\mathrm{Pb}$ (II) and $\mathrm{Fe}(\mathrm{III})$ ions. The values of $\mathrm{Z}$ in Table 3 indicate an expansion in the surface layer and a diminished external mass transfer while the potential for internal mass transfer increased.

The mechanism for the removal of metals via adsorption occurred in several steps. In the first step, the metal ions migrate from the solution to the external surface of the adsorbent. This was followed by the diffusion through the boundary layer to the active sites. Finally, intraparticle diffusion and the adsorption of metal ions in the inner part of the polymer occurred. The valid mechanism in this work was examined by the two models: the liquid-film model and the intraparticle-diffusion model. The liquid-film diffusion model (Eq. 10) assumed that the flow of the adsorbate molecules through a liquid film surrounding the adsorbent was the rate-determining step. According to Eq. 10, a linear plot of $-\ln (1-F) v s . t$ (Fig. 6) with a zero intercept suggested that the kinetics of the adsorption process were controlled by diffusion through the surrounding liquid film. As shown in Fig. 6, the experimental adsorption data of the metals by cell-o-PDAm from an aqueous solution at different temperatures did not provide straight lines that passed through the origin, and had coefficients of determination 0.1876 and 0.1578 for $\mathrm{Fe}$ (III) and $\mathrm{Pb}$ (II) (Table 5), respectively. This indicated that the diffusion of the metals through the liquid film around the cellulose-amine was not the rate-determining step, but may contribute to the adsorption process, especially at the beginning of the adsorption as shown in Table 3.

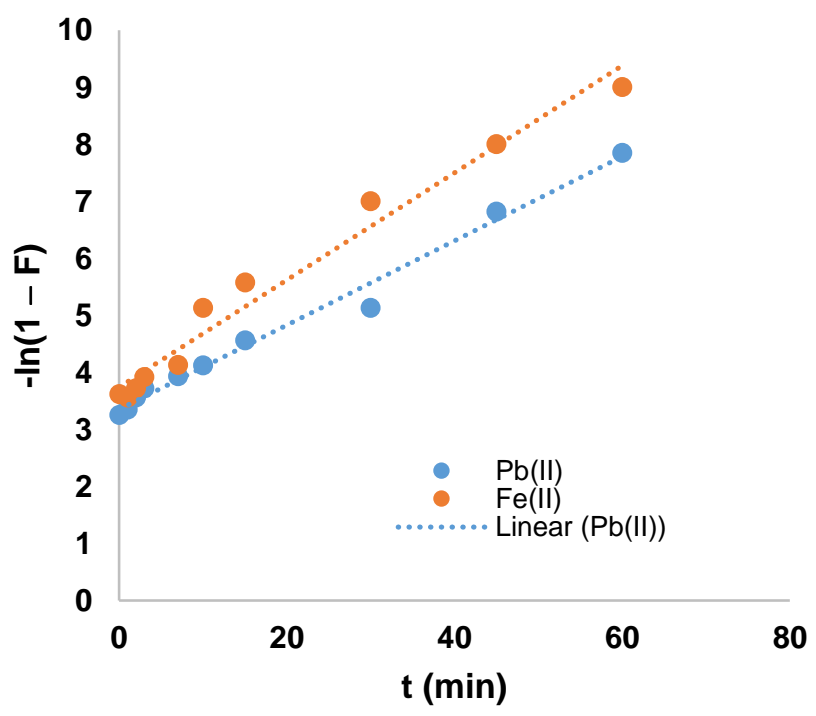

Fig. 6. Liquid film diffusion model plots for the adsorption of composite based of cellulose 
Table 4. Liquid Film Diffusion Model Parameters

\begin{tabular}{|c|c|c|}
\hline & $K_{\mathrm{df}}$ & $\mathrm{R}^{2}$ \\
\hline $\mathrm{Fe}(\mathrm{II})$ & 0.1876 & 0.9735 \\
\hline $\mathbf{P b}(\mathrm{II})$ & 0.1578 & 0.9873 \\
\hline
\end{tabular}

\section{Adsorption Thermodynamics}

The Gibbs free energy $\left(\Delta G_{0}\right)$, enthalpy $\left(\Delta H_{0}\right)$, and entropy $\left(\Delta S_{0}\right)$ were calculated according to the following equations and the results are summarized in Table 5 . These are important when evaluating the behavior of the adsorption of $\mathrm{Pb}(\mathrm{II})$ and $\mathrm{Fe}$ (III) ions on cello-PDAm. The equations are as follows,

$$
\begin{aligned}
& K_{\mathrm{c}}=\frac{C_{\mathrm{ads}}}{C_{\mathrm{e}}} \\
& \Delta \mathrm{G}^{\circ}=-R T \ln K_{\mathrm{c}} \\
& \ln K_{\mathrm{s}}=\frac{\Delta S}{R}-\frac{\Delta H}{R T}
\end{aligned}
$$

where $K_{\mathrm{c}}$ is an apparent constant of the thermodynamics, $C_{a \mathrm{ds}}$ is the amount adsorbed at equilibrium $(\mathrm{mg} / \mathrm{L}), C_{\mathrm{e}}$ is the equilibrium concentration in an aqueous solution of metal ion $(\mathrm{mg} / \mathrm{L}), R$ is the gas constant $(\mathrm{J} / \mathrm{mol} \times \mathrm{K})$, and $T$ is the ions solution temperature $(\mathrm{K})$ (Azzaoui and Mejdoubi 2014).

\begin{tabular}{|c|c|c|c|c|c|c|}
\hline $\mathrm{T}(\mathrm{K})$ & \multicolumn{3}{|c|}{$\mathrm{Fe}(\mathrm{III})$} & \multicolumn{3}{|c|}{$\mathrm{Pb}(\mathrm{II})$} \\
\hline & $\begin{array}{c}\Delta G^{\circ} \\
(\mathrm{KJ} / \mathrm{mol})\end{array}$ & $\begin{array}{c}\Delta H^{\circ} \\
(\mathrm{KJ} / \mathrm{mol})\end{array}$ & $\begin{array}{c}\Delta S^{\circ} \\
(\mathrm{J} / \mathrm{K} \cdot \mathrm{mol})\end{array}$ & $\begin{array}{c}\Delta G^{\circ} \\
(\mathrm{KJ} / \mathrm{mol})\end{array}$ & $\begin{array}{c}\Delta H^{\circ} \\
(\mathrm{KJ} / \mathrm{mol})\end{array}$ & $\Delta S^{\circ}(\mathrm{KJ} / \mathrm{mol})$ \\
\hline 298 & -17.144 & \multirow{3}{*}{9.66368} & \multirow{3}{*}{57.5627} & -18.6156 & \multirow{3}{*}{16.4161} & \multirow{3}{*}{77.9326} \\
\hline 313 & -17.0074 & & & -19.5535 & & \\
\hline 323 & -18.5832 & & & -20.1787 & & \\
\hline
\end{tabular}

Table 5. Thermodynamic Parameters for the Adsorption of $\mathrm{Pb}(\mathrm{II})$ and $\mathrm{Fe}(\mathrm{III})$ ions onto Cell-oPDAm

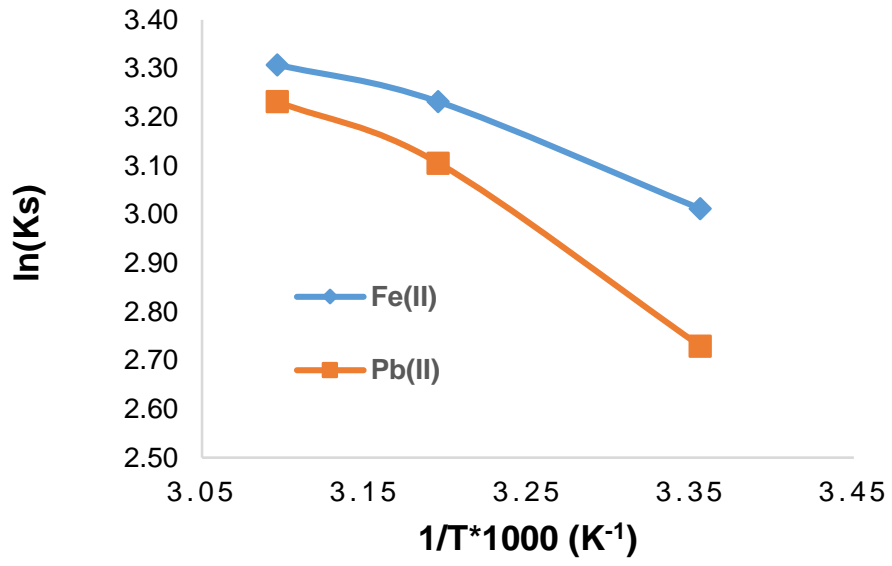

Fig. 7. Adsorption thermodynamics of $\mathrm{Pb}(\mathrm{II})$ and $\mathrm{Fe}(\mathrm{III})$ ions by cell-o-PDAm 
The $K_{\mathrm{c}}$ value was calculated according to the Van't Hoff equation (Eq. 11) (Zhang et al. 2010). The standard Gibbs free energy $\left(\Delta G_{0}\right)\left(\mathrm{Jmol}^{-1}\right)$ was calculated using Eq. 12. The $\ln \left(K_{\mathrm{s}}\right)$ versus $1 / T$ was plotted as shown in Fig. 7 . The slopes and the intercept were used to calculate various thermodynamics parameters; results are shown in Table 5. The obtained values of $\Delta S_{0}$ and $\Delta H_{0}$ were positive, while the entropy increased at the solid/solution interface, driven by the adsorption process. The free energies were negative, indicating a spontaneous adsorption process at the tested temperatures.

\section{CONCLUSIONS}

1. Cellulose powder derivatized with an aromatic amine chelating agent (cell-o-PDAm) was successfully prepared from cellulose powder extracted from olive industry solid waste.

2. The efficiency of the prepared cell-o-PDAm toward adsorbing the metal ions Fe(III) and $\mathrm{Pb}$ (II) was studied as a function of adsorbent dose, temperature, $\mathrm{pH}$, metal ion initial concertation, and time.

3. The cell-o-PDAm polymer showed an excellent efficiency toward both metals, the highest absorbency was observed at a $\mathrm{pH}$ of approximately 8.0 and at room temperature.

4. The polymer showed excellent efficiency for metal ions present in a real sample of sewage.

5. The kinetic study revealed that the metal ion adsorption by cell-o-PDAm was pseudosecond-order and followed the Langmuir isotherm model.

6. The thermodynamic analysis showed a negative free energy, indicating a spontaneous adsorption process at different temperatures.

\section{ACKNOWLEDGEMENTS}

The authors want to thank the Palestinian Ministry of Higher Education for their financial support of this work. The authors want to acknowledge the An-Najah National University in Palestine for Polymer Metal and Polymer Analysis.

\section{REFERENCES CITED}

Abdel-Ghani, N. T., Hefny, M., and El-Chaghaby, G. A. F. (2007). "Removal of lead from aqueous solution using low cost abundantly available adsorbents," International Journal of Environmental Science and Technology 4(1), 67-73.

Acar, F. N., and Eren, Z. (2006). "Removal of Cu(II) ions by activated poplar sawdust (Samsun clone) from aqueous solutions," Journal of Hazardous Materials 137(2), 909-914. DOI: 10.1016/j.hazmat.2006.03.014

Adeyemo, A. A., Adeoye, I. O., and Bello, O. S. (2017). "Adsorption of dyes using different types of clay: A review," Applied Water Science 7(2), 543-568.DOI: 10.1007/s13201-015-0322-y 
Algarra, M., Bartolić, D., Radotić, K., Mutavdžić, D., Pino-González, M. S., RodríguezCastellón, E., Lázaro-Martínez, J. M., Guerrero-González, J. J., Esteves da Silva, J. C. G., and Jiménez-Jiménez, J. (2019). "P-doped carbon nano-powders for fingerprint imaging," Talanta 194, 150-157. DOI: 10.1016/j.talanta.2018.10.033

Azzaoui, K., and Mejdoubi, E. (2014). Elaboration and Study of Some Composites Based on Phosphocalcic Hydroxyapatite, Intended for Industrial and Medical Uses, Faculty of Sciences, Mohamed $1^{\text {st }}$ University, Oujda, Morocco.

Bo, S., Ren, W., Lei, C., Xie, Y., Cai, Y., Wang, S., Gao, J., Ni, Q., and Yao, J. (2018). "Flexible and porous cellulose aerogels/zeolitic imidazolate framework (ZIF-8) hybrids for adsorption removal of Cr(IV) from water," Journal of Solid State Chemistry 262, 135-141. DOI: 10.1016/j.jssc.2018.02.022

Chwastowski, J., Staroń, P., Kołoczek, H., and Banach, M. (2017). “Adsorption of hexavalent chromium from aqueous solutions using Canadian peat and coconut fiber," Journal of Molecular Liquids 248, 981-989.DOI: 10.1016/j.molliq.2017.10.152

Doan, H. D., Lohi, A., Dang, V. B. H., and Dang-Vu, T. (2008). "Removal of $\mathrm{Zn}^{+2}$ and $\mathrm{Ni}^{+2}$ by adsorption in a fixed bed of wheat straw," Process Safety and Environmental Protection 86(4), 259-267.DOI: 10.1016/j.psep.2008.04.004

Guo, X., Zhang, S., and Shan, X. Q. (2008). “Adsorption of metal ions on lignin,” Journal of Hazardous Materials 151(1), 134-142. DOI: 10.1016/j.jhazmat.2007.05.065

Gupta, V. K., Nayak, A., and Agarwal, S. (2015). "Bioadsorbents for remediation of heavy metals: Current status and their future prospects," Environmental Engineering Research 20(1), 1-18. DOI: 10.4491/eer.2015.018

Gupta, S., and Babu, B. V. (2009). "Utilization of waste product (tamarind seeds) for the removal of $\mathrm{Cr}(\mathrm{VI})$ from aqueous solutions: Equilibrium, kinetics, and regeneration studies," Journal of Environmental Management 90(10), 3013-3022. DOI: 10.1016/j.jenvman.2009.04.006

Hamed, O., Fouad, Y., Hamed, E. M., and Al-Hajj, N. (2012). "Cellulose powder from olive industry solid waste," BioResources 7(3), 4190-4201. DOI: 10.15376/biores.7.3.4190-4201

Hamed, O., Jodeh, S., Al-Hajj, N., Abo-Obeid, A., Hamed, E. M., and Fouad, Y. (2014). "Cellulose acetate from biomass waste of olive industry," Journal of Wood Science 61(1), 45-62. DOI: 10.1007/s10086-014-1442-y

Heinze, T., and Liebert, T. (2001). "Unconventional methods in cellulose functionalization,” Progress in Polymer Science 26(9), 1689-1762. DOI: 10.1016/S0079-6700(01)00022-3

Hokkanen, S., Bhatnagar, A., and Sillanpa, M. (2016). "A review on modification methods to cellulose-based adsorbents to improve adsorption capacity," Water Research 91, 156-173. DOI: 10.1016/j.watres.2016.01.008

Jodeh, S., Amarah, J., Radi, S., Hamed, O., Warad, I., Salghi, R., Chetouni, A., Samhan, S., and Alkowni, R. (2016). "Removal of methylene blue from industrial wastewater in Palestine using polysiloxane surface modified with bipyrazolictripodal receptor," Morocco Journal of Chemistry 4(1), 140-156.

Jodeh, S., Hamed, O., Melhem, A., Salghi, R., Jodeh, D., Azzaoui, K., Benmassaoud, Y., and Murtada, K. (2018). "Magnetic nanocellulose from olive industry solid waste for the effective removal of methylene blue from wastewater," Environmental Science and Pollution Research 25(22), 22060-22074. DOI: 10.1007/s11356-018-2107-y 
Karnitz, Jr., O., Gurgel, L. V. A., De Melo, J. C. P., Botaro, V. R., Melo, T. M. S., De Freitas Gil, R. P., and Gil, L. F. (2007). "Adsorption of heavy metal ion from aqueous single metal solution by chemically modified sugarcane bagasse," Bioresource Technology 98(6), 1291-1297. DOI: 10.1016/j.biortech.2006.05.013

Kim, U. J., Kuga, S., Wada, M., Okano, T., and Kondo, T. (2000). "Periodate oxidation of crystalline cellulose," Biomacromolecules 1(3), 488-492.DOI: $10.1021 / \mathrm{bm} 0000337$

Lázaro-Martínez, J. M., Romasanta, P. N., Chattah, A. K., and Buldain, G. Y. (2010). "NMR characterization of hydrate and aldehyde forms of imidazole-2carboxaldehyde and derivatives," The Journal of Organic Chemistry 75(10), 32083213. DOI: $10.1021 /$ jo902588s

Limousin, G., Gaudet, J. P., Charlet, L., Szenknect, S., Barthès, V., and Krimissa, M. (2007). "Sorption isotherms: A review on physical bases, modeling and measurement," Applied Geochemistry 22(2), 249-275. DOI: 10.1016/j.apgeochem.2006.09.010

Lin, J., Chen, X., Chen, C., Hu, J., Zhou, C., Cai, X., Wang, W., Zheng, C., Zhang, P., Cheng, J., et al. (2018). "Durably antibacterial and bacterially anti-adhesive cotton fabrics coated by cationic fluorinated polymers," ACS Applied Materials \& Interfaces 10(7), 6124-6136. DOI: 10.1021/acsami.7b16235

Liu, B., Wang, D., Yu, G., and Meng, X. (2013). "Removal of F- from aqueous solution using $\mathrm{Zr}(\mathrm{IV})$ impregnated dithiocarbamate modified chitosan beads," Chemical Engineering Journal 228, 224-231. DOI: 10.1016/j.cej.2013.04.099

Milieu Ltd., WRc, and Risk \& Policy Analysts Ltd. for the European Commission (2010). "Environmental, economic and social impacts of the use of sewage sludge on land," (http://ec. europa.eu/environment/waste/sludge/pdf/part iii report.pdf), Accessed 02 Aug 2011.

Moa, J., Yanga, Q., Zhang, N., Zhang, W., Zheng, Y., and Zhang, Z. (2018). "Review on agro-industrial waste (AIW) derived adsorbents for water and wastewater treatment," Journal of Environmental Management 227, 395-405. DOI: 10.1016/j.jenvman.2018.08.069

Muhammad, R. R., Nor, A. Y., Mohammad, J. H., Norazowa, I., Faruq, M., Sazlinda, K., and Hamad, A. A.-L. (2018). "Iminodiacetic acid modified kenaf fiber for waste water treatment," International Journal of Biological Macromolecules 112, 754-760. DOI: 10.1016/j.ijbiomac.2018.02.035

Nada, A. M. A., Eid, M. A., El Bahnasawy, R. M., and Khalifa, M. N. (2002). "Preparation and characterization of cation exchangers from agricultural residues," Journal of Applied Polymer Science 85(4), 792-800. DOI: 10.1002/app. 10647

Nagy, B., Maicaneanu, A., Indolean, C., Burca, S., Silaghi, L., and Majdik, C. (2013). "Cadmium (II) ions removal from aqueous solutions using Romanian untreated fir tree sawdust - A green biosorbent," Acta Chimica. Slovenica 60(2), 263-273.

O'Connell, D. W., Birkinshaw, C., and O'Dwyer, T. F. (2008). "Heavy metal adsorbents prepared from the modification of cellulose: A review," Bioresource Technology 99(15), 6709-6724. DOI: 10.1016/j.biortech.2008.01.036

Qaiser, S., Saleemi, A. R., and Umar, M. (2009). "Biosorption of lead from aqueous solution by Ficusreligiosa leaves: Batch and column study," Journal of Hazardous Materials 166(2-3), 998-1005. DOI: 10.1016/j.ijhazmat.2008.12.003 
Sahmoune, M. N., Louhab, K., and Boukhiar, A. (2011). “Advanced biosorbents materials for removal of chromium from water and wastewaters," Environmental Progress \& Sustainable Energy 30(3), 284-293. DOI: 10.1002/ep.10473

Saravanan, R., and Ravikumar, L. (2015). "The use of new chemically modified cellulose for heavy metal ion adsorption and antimicrobial activities, " Journal of Water Resource and Protection 7(6), 530-545. DOI: 10.4236/jwarp.2015.76042

Sud, D., Mahajan, G., and Kaur, M. P. (2008). "Agricultural waste material as potential adsorbent for sequestering heavy metal ions from aqueous solutions - A review," Bioresource Technology 99(14), 6017-6027. DOI: 10.1016/j.biortech.2007.11.064

Uddin, M. K. (2017). "A review on the adsorption of heavy metals by clay minerals, with special focus on the past decade," Chemical Engineering Journal 308, 438-462. DOI: 10.1016/j.cej.2016.09.029

Vieira, M.G. A., De Almeida Neto, A. F., Da Silva, M. G. C., Carneiro, C.N., and DeMelo Filho, A. A. (2014). "Adsorption of lead and copper ions from aqueous affluents on rice husk ash in a dynamic system," Brazilian Journal of Chemistry Engineering 31(2), 519-529. DOI: 10.1590/0104-6632.20140312s00002103

Zelić, E., Vuković, Z., and Halkijević, I. (2018). "Application of nanotechnology in wastewater treatment," Građevinar 70(4), 315-323. DOI: 10.14256/JCE2165.2017

Zhang, Z., Li, M., Chen, W., Zhu, S., Liu, N., and Zhu, L. (2010). "Immobilization of lead and cadmium from aqueous solution and contaminated sediment using nanohydroxyapatite," Environmental Pollution 158(2), 514-519. DOI: 10.1016/j.encpol.2009.08.024

Zhao, X., Wang, W., Zhang, Y., Wu, S., Li, F., and Liu, J. P. (2014). "Synthesis and characterization of gadolinium doped cobalt ferrite nanoparticles with enhanced adsorption capability for Congo Red," Chemical Engineering Journal 250, 164-174. DOI: $10.1016 /$ j.cej.2014.03.113

Article submitted: March 26, 2019; Peer review completed: June 3, 2019; Revised version received: June 8, 2019; Accepted: June 10, 2019; Published: June 19, 2019. DOI: $10.15376 /$ biores.14.3.6247-6266 


\section{APPENDIX}

\section{Supplementary Information}

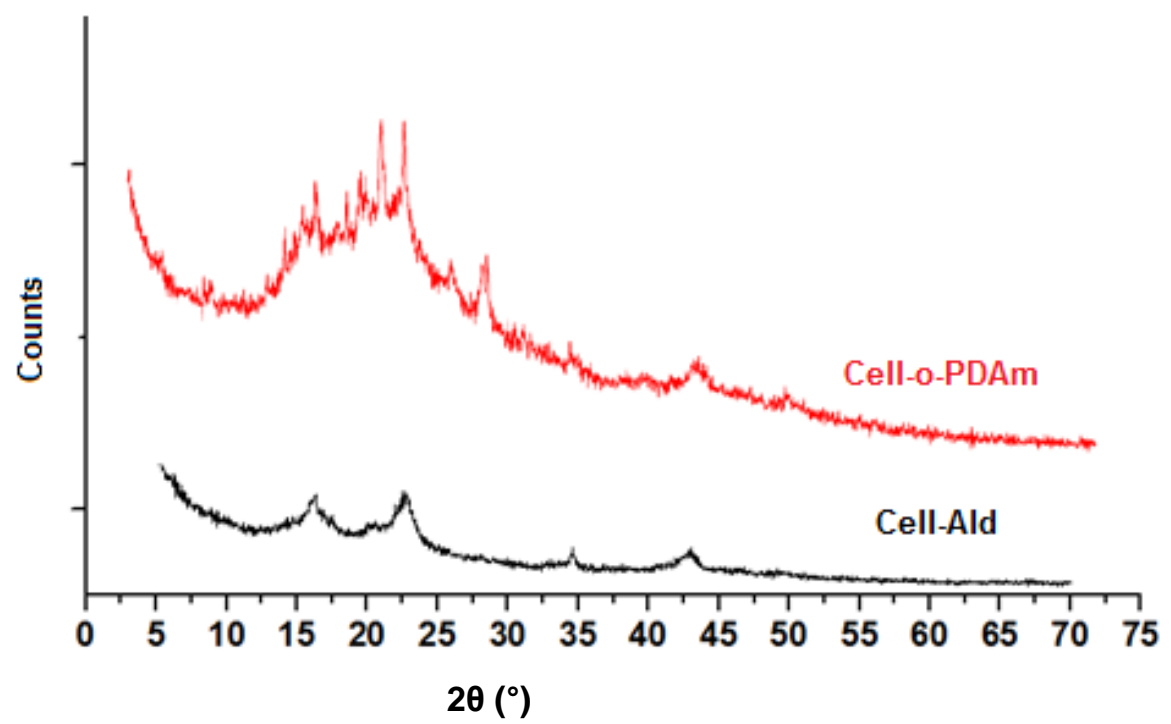

Fig. S1. XRD spectra of cellulose aldehyde and cell-o-PDAM

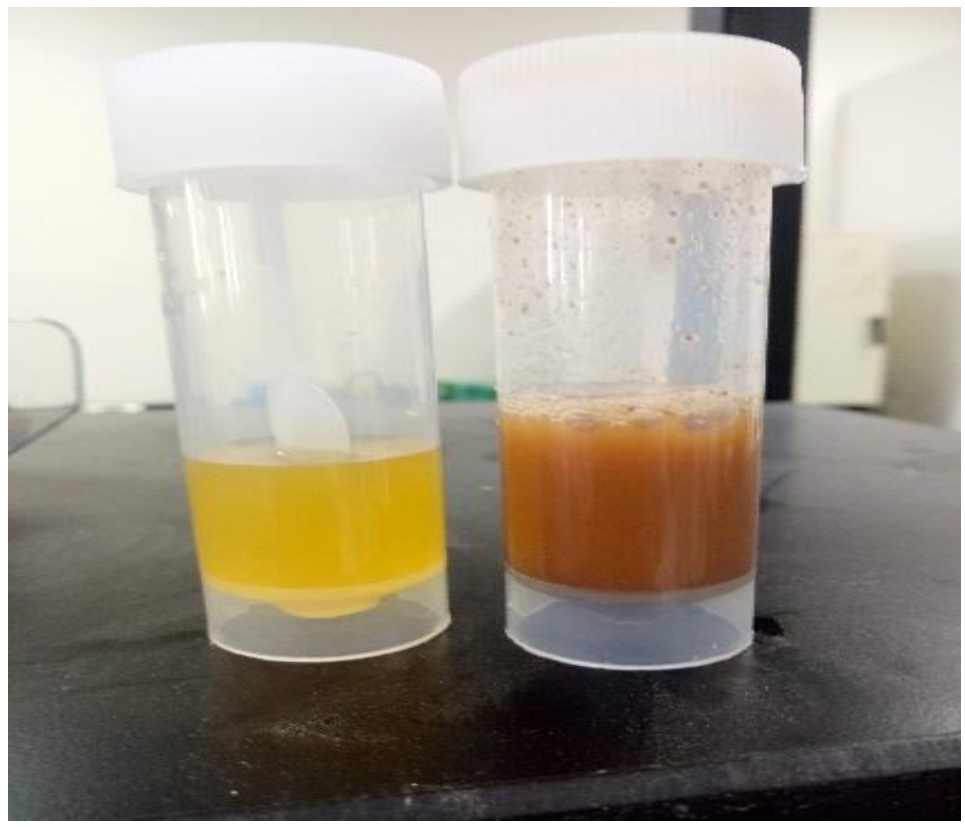

Fig. S2. Images of wastewater sample before and after treatment with cell-o-PDAm 


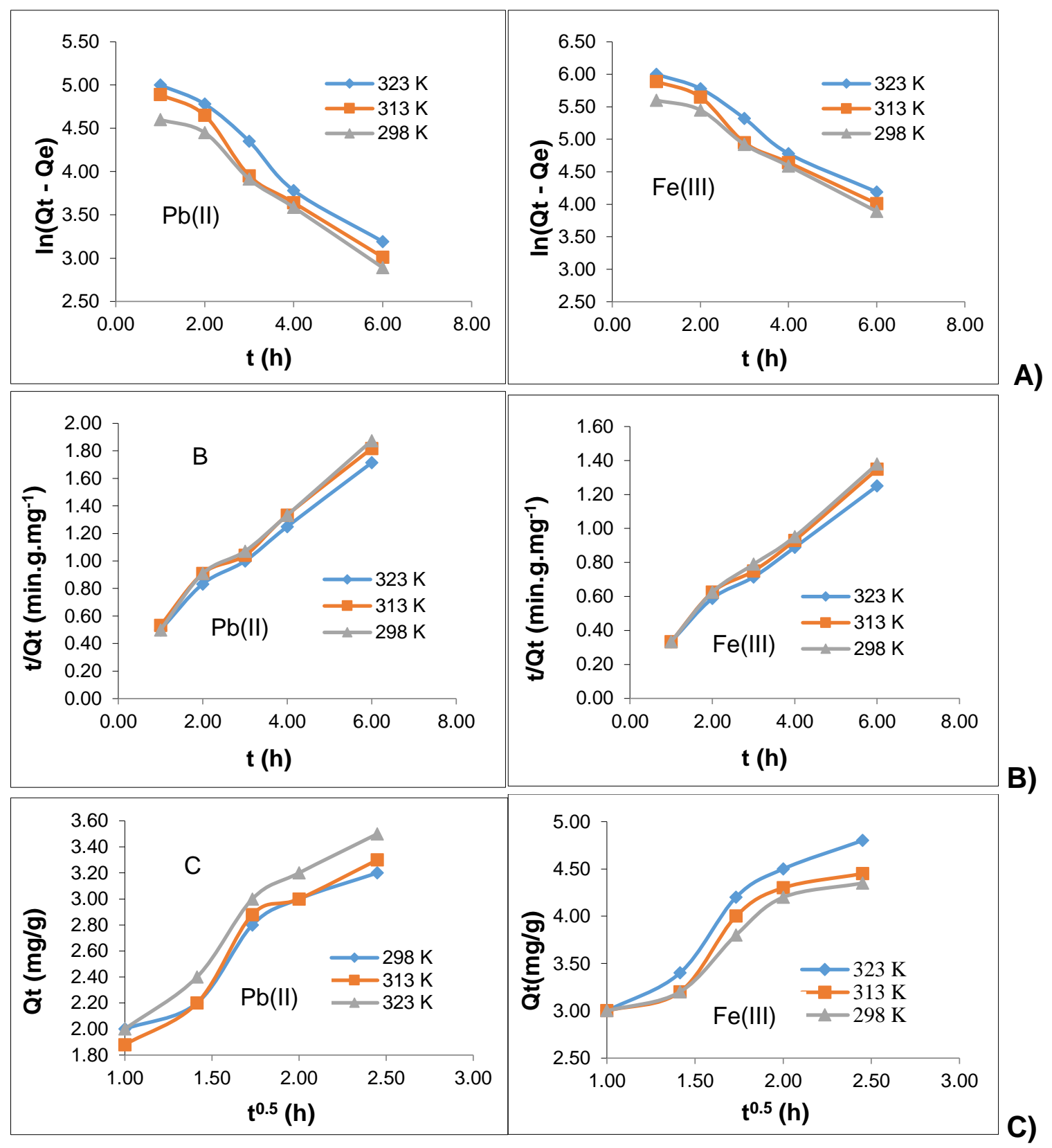

Fig. S3. A) Pseudo-first-order model for the adsorption of $\mathrm{Pb}(\mathrm{II})$ and $\mathrm{Fe}(\mathrm{III})$; B) Pseudo-secondorder model for the adsorption of $\mathrm{Pb}(\mathrm{II})$ and $\mathrm{Fe}(\mathrm{II})$ ions by cell-o-PDAm; $\mathrm{C}$ ) Intraparticle diffusion model for the adsorption of $\mathrm{Pb}(\mathrm{II})$ and $\mathrm{Fe}(\mathrm{III})$ ions by cell-o-PDAm polymer at various concentrations 